\title{
Evaluation of Constipation Risk among Inpatients in Surgery and Internal Medicine Wards
}

\section{Cerrahi ve Dahili Kliniklerde Yatan Hastalarda Konstipasyon Riskinin Değerlendirilmesi}

\author{
(1) Şenay Karadağ Arlı \\ Ağrı İbrahim Çeçen University, School of Health, Ağrı, Turkey
}

\section{HIIIIII| ABSTRACT}

Aim: This study was conducted to evaluate the risk of constipation among inpatients in the surgery and internal medicine wards.

Method: This descriptive study included 251 inpatients being treated in the Ağrı State Hospital between April 2018 and June 2018 who consented to participate. Data were collected using a personal information form and the constipation risk assessment scale (CRAS).

Results: The mean age of the participants was $49.74 \pm 19.50$ years. Analysis of the patients' distributions according to mean CRAS score and sociodemographic characteristics showed that gender, marital status, education level, and occupation were statistically significant ( $\mathrm{p}<0.05$, $\mathrm{p}<0.01$ ). In addition, when the distribution of the patients according to mean CRAS total score and health status/lifestyle characteristics was examined, statistically significant differences were observed in terms of hospital ward, presence of chronic disease, regular medication use, predominant food group, skipping meals, regular exercise, constipation problem, and constipation risk $(\mathrm{p}<0.05, \mathrm{p}<0.01)$. There was a statistically significant positive correlation between total CRAS score and age $(\mathrm{p}<0.01)$.

Conclusion: Older age was associated with more problems with constipation in our study group. Therefore, it is recommended to prevent or solve the problem through constipation risk assessment for inpatients, early diagnosis of constipation, appropriate nursing interventions, and team collaboration.

Keywords: Constipation, constipation risk assessment, constipation care

\section{|IIIIIII| ÖZ}

Amaç: $\mathrm{Bu}$ araştırma, cerrahi ve dahili kliniklerde yatan hastalarda konstipasyon riskinin değerlendirilmesi amacıyla yapıldı.

Yöntem: Tanımlayıcı tipteki çalışma, Ağnı Devlet Hastanesi'nde Nisan 2018-Haziran 2018 tarihleri arasında servislerde yatan ve çalışmayı kabul eden 251 hastanın katılımıyla yapıldı. Veriler kişisel bilgi formu ve konstipasyon risk değerlendirme ölçeği (KRDÖ) kullanılarak toplandı.

Bulgular: Araştırmaya katılanların yaş ortalaması 49,74 19,50 idi. Araştırmaya katılan hastaların KRDÖ toplam puan ortalamaları ile sosyo-demografik özelliklerine göre dağılımları incelendiğinde; cinsiyet, medeni durum, eğitim durumu ve meslek özellikleri arasında istatistiksel olarak anlamlı fark olduğu bulundu $(\mathrm{p}<0,05, \mathrm{p}<0,01)$. Ayrıca, hastaların KRDÖ toplam puan ortalamaları ile sağlık durumu ve yaşam tarzı özelliklerine göre dağılımları incelendiğinde; hastanın yattığı servis, kronik hastalık durumu, düzenli ilaç kullanımı, en çok tüketilen besin grubu, ögüt atlama durumu, düzenli egzersiz yapma, kabızlık sorunu ve konstipasyon riski özellikleri açısından istatistiksel olarak anlamlı fark olduğu belirlendi (p<0,05, p<0,01). KRDÖ toplam puanı ile yaş arasında pozitif yönde istatistiksel açıdan anlamlı bir ilişki olduğu bulundu ( $\mathrm{p}<0,01)$.

Sonuç: Çalışmaya katılan hastaların yaşları arttıkça, konstipasyon sorununu daha fazla yaşadıkları belirlendi. Bu nedenle özellikle yatan hastaların konstipasyon risk değerlendirilmesinin yapılması, konstipasyon sorununun erken dönemde tanılanması, uygun hemşirelik girişimleri ve ekip iş birliği ile sorunun önlenmesi ya da çözülmesi önerilmektedir.

Anahtar Kelimeler: Konstipasyon, konstipasyon risk değerlendirmesi, konstipasyonda bakım

Address for Correspondence/Yazışma Adresi: Şenay Karadağ Arlı, Ağrı İbrahim Çeçen University, School of Health, Ağrı, Turkey 


\section{Introduction}

Constipation is a clinical entity of variable etiology that can cause complaints such as abdominal pain, bloating, cramps, nausea, vomiting, and malnutrition. ${ }^{1,2,3}$ It is also described as a condition that affects both body and mind, causing feelings of panic and helplessness. Due to the nature of this problem, patients find it difficult to discuss and often feel that medical personnel do not give it sufficient consideration. ${ }^{4}$ Constipation also increases the risk of megacolon, volvulus, colorectal cancer, and psychological conditions such as depression and mood disorders. ${ }^{5,6}$

Several risk factors and etiologies have been reported in relation to the development of constipation. A review of factors associated with constipation reported pelvic floor dysfunction (hernia, prolapse), colorectal disorders (irritable bowel syndrome, tumors), neuromuscular disorders (Parkinson's disease, stroke) and metabolic disorders (diabetes, hypokalemia) among its causes. ${ }^{7}$ It has also been reported that psychological disorders like depression are associated with constipation, and the prevalence of constipation was found to be significantly higher among individuals with dementia compared to a control group. ${ }^{8}$ In addition, certain medications, such as opioid analgesics and drugs with anticholinergic properties, are known to provoke constipation. ${ }^{7,9}$ Associations between constipation and low mobility, dehydration, addiction, and nutritional problems have also been reported. ${ }^{10,11}$

Constipation is a common health problem in the general population, with an incidence of $2-28 \%$ reported in the literature. ${ }^{12,13}$ According to the results of population-based studies conducted in Turkey, the incidence of constipation varies between $22-40 \%$ in our country. ${ }^{14}$ Various studies have shown that constipation is more common in females than males, in blacks versus whites, and in children and the elderly compared to adults. ${ }^{15}$ In particular, the bowel habits of hospital inpatients change due to immobility during treatment, the effects of some drugs, and staying in the hospital, which can cause constipation. In patients undergoing surgery, constipation risk increases in the early postoperative period due to being bedbound, taking opioid/ non-opioid analgesic drugs, and having to defecate while in bed using a bedpan. Postoperative constipation prolongs hospital stays, causes comorbidity in addition to the existing disorders, and adversely affects patients' quality of life..$^{12,16}$ The aim of the current study was to assess constipation risk among patients hospitalized in the internal medicine and general surgery departments for any reason.

\section{Materials and Methods}

\section{Research Design}

This is a descriptive study.
Population and sample: The study population consisted of patients admitted to various units of Ağrı State Hospital between April 2018 and June 2018. The study sample included patients hospitalized in the internal medicine and surgery departments of Ağrı State Hospital who volunteered to participate in the study, were over 18 years of age, and had no communication problems.

\section{Data Collection Tools}

Personal data form: Consisted of 16 questions prepared by the researchers to gather descriptive data about the patients.

Constipation risk assessment scale: Developed in 2005 by Richmond and Wright. ${ }^{17}$ Validity and reliability studies for the Turkish version of the constipation risk assessment scale (CRAS) were conducted by Kutlu et al. ${ }^{18}$ in 2010. The scale consists of four sections including lifestyle, hospital-related factors, physiological and psychological conditions, and drugs that increase constipation risk. The lifestyle section has five subheadings: gender, mobility, fiber intake, fluid intake, and personal beliefs. There are a total of 16 questions under these five subheadings. The hospital-related section has two subcategories, one for ward patients only and one for patients who require a bedpan. There are a total of two questions under these two subheadings. The physiological and psychological conditions section has seven subheadings: metabolic disorders, pelvic conditions, neuromuscular disorders, endocrine disorders, colorectal/abdominal disorders, psychiatric illnesses, and learning disabilities/ dementia. There are six subheadings in the section regarding drugs that increase constipation risk: antiemetics, calcium channel blockers, iron supplements, anticholinergiccontaining drugs, analgesics, and cytotoxic chemotherapy. Subscores are written at the end of each section and the total score is used to determine the patient's constipation risk group. A subtotal of 1-11 points can be obtained in the lifestyle section, 0-4 for hospital-related factors, 0-18 for physiological and psychological conditions, and 0-30 points in the section about drugs that increase constipation risk. Therefore, the total score obtained from the CRAS is between 1 and 63. A score of 1-10 is considered low risk, 11-15 as moderate risk, and 16 or more as high risk. ${ }^{17,18}$

Data collection: The study data were collected in face-toface interviews with inpatients in the internal medicine and surgery units between April 2018 and June 2018. Completing the data collection forms took about 10 minutes.

Data analysis: Data analysis was done using SPSS statistics software. Data were analyzed using numbers, percents, mean, Kolmogorov-Smirnov test, Kruskal-Wallis test, Mann-Whitney U test, and Spearman correlation analysis. 
Table 2. Distribution of the patients' mean total constipation risk assessment scale scores according to health status and lifestyle characteristics $(\mathrm{n}=251)$

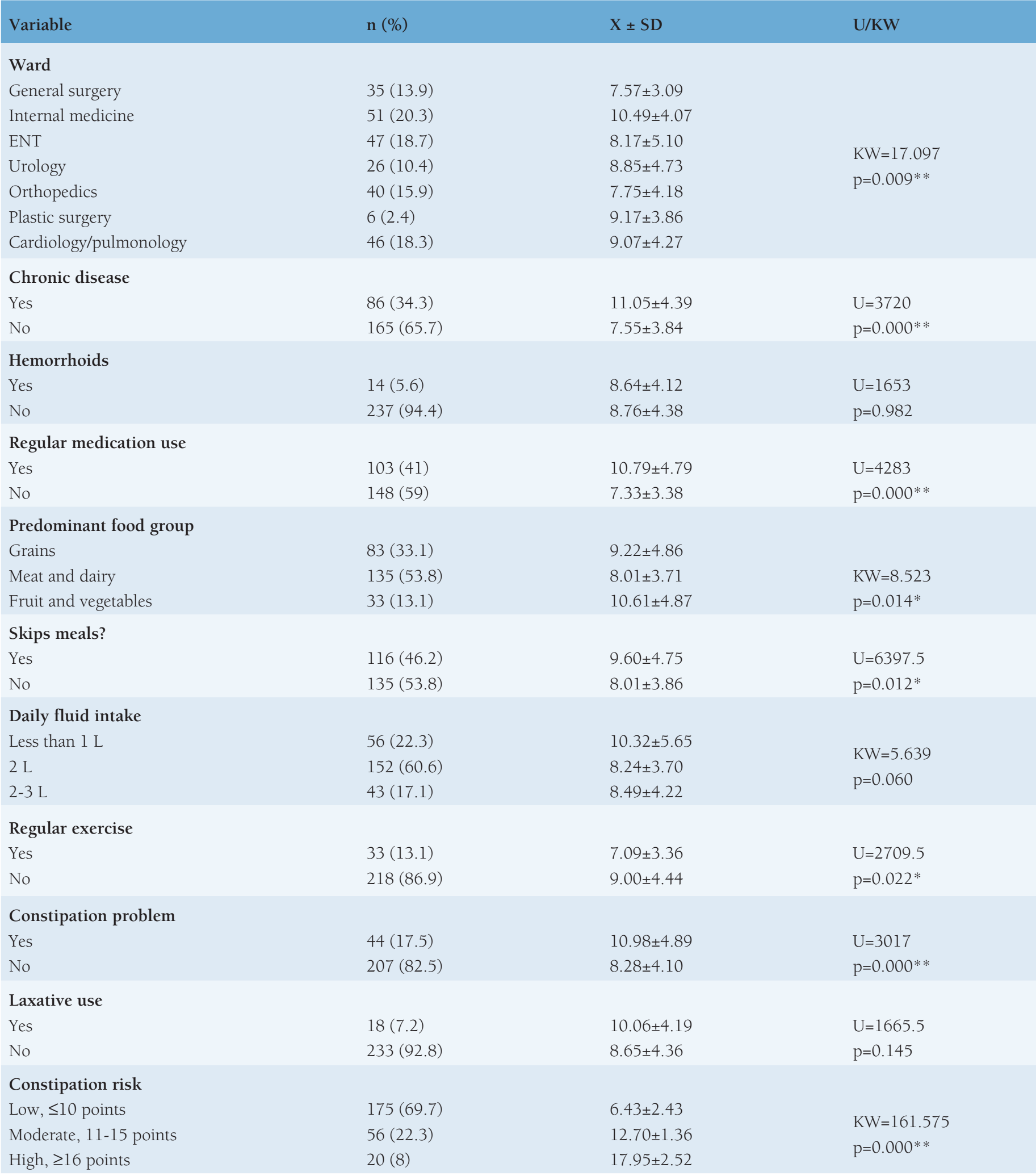

ENT: Otorhinolaryngology, KW: Kruskal-Wallis, SD: Standard deviation, X: Mean ${ }^{*} \mathrm{p}<0.05, * * \mathrm{p}<0.01$ 
Table 3. Correlation between constipation risk assessment scale total score and age

$\begin{array}{cll} & & \begin{array}{l}\text { Constipation risk assessment scale } \\ \text { total score }\end{array} \\ \text { Age } & \text { r } & 0.342 * \\ & \text { p } & 0.000 \\ * \mathrm{p}<0.01 & & \end{array}$

samples, constipation was reported to be twice as common in females than in males. ${ }^{15,21,22}$ Bilgiç et al. ${ }^{23}$ also found that women experienced constipation more often than men. Similarly, the female participants had a higher mean constipation risk score. It has been shown in the literature that low education level is associated with higher prevalence of constipation. ${ }^{15,24}$ Our finding of higher mean constipation risk score among the illiterate participants in this study supports the literature. This suggests a possible link between education level and diet.

Constipation is one of the most common postoperative complications. The prevalence of constipation among inpatients has been reported as $79 \% .{ }^{25}$ According to a study by Celik et al., ${ }^{26} 25-40 \%$ of patients hospitalized for abdominal surgery had evacuation difficulty. In the current study, patients in the internal medicine ward were found to have higher mean constipation risk score. This may be because patients being treated in internal medicine are those with extended hospital stays, restricted movement, and regular medications due to chronic diseases.

Studies have indicated a negative correlation between constipation and physical activity. ${ }^{27,28}$ Uysal et al. ${ }^{29}$ determined that constipation was more common in people who did not exercise and had a sedentary lifestyle. In the literature, sedentary lifestyle is a well documented risk factor for constipation. ${ }^{12,16,26,30}$ In a study conducted in women having constipation, $74.3 \%$ were found to have a sedentary lifestyle. ${ }^{31}$ Consistent with the literature, the group of participants in our study who reported not exercising regularly had a higher mean constipation risk score.

The results of a study by Sendir et al. ${ }^{16}$ indicated that the patients were in the moderate risk group with a mean CRAS score of $12.73 \pm 4.75$. On the other hand, the mean CRAS scores obtained in our study showed that most of the participants were in the low-risk group. Most studies have shown that the prevalence of constipation increases with older age. Evidence suggests that constipation incidence increases with age, with $40 \%$ of those aged 65 and older having problems with constipation. ${ }^{21,22}$ It is one of the common complaints of geriatric patients and can result in morbidity among elderly nursing homes residents. ${ }^{32,33}$
Constipation has been described as a distressing, chronic, and recurrent problem that affects approximately 50-73\% of elderly nursing home residents. ${ }^{34}$ Bailes and Reeve ${ }^{35}$ determined that $28 \%$ of males aged 84 and over experienced constipation. In accordance with literature data, the present study revealed a significant positive correlation between patient age and constipation risk.

In conclusion, this study elucidated risk factors affecting constipation and relationships among them. It is clear that older age in particular is a significant and nonmodifiable risk factor. However, constipation can be prevented or resolved by managing the other risk factors based on the patient's current condition. We recommend that nurses, as one of the members of the medical team who have the most contact with patients, conduct constipation risk assessment for inpatients, work in cooperation with the medical staff, and prepare guidelines regarding this issue.

\section{Ethics}

Ethics Committee Approval: The study was approved by the Ağrı İbrahim Çeçen University Local Ethics Committee (approval number: 95531838-900).

Informed Consent: Consent form was filled out by all participants.

Peer-review: External and internal peer-reviewed.

\section{Authorship Contributions}

Concept: Ş.K.A., Design: S..K.A., Data Collection or Processing: Ş.K.A., Analysis or Interpretation: Ş.K.A., Literature Search: Ş.K.A., Writing: S..K.A.

Conflict of Interest: No conflict of interest was declared by the authors.

Financial Disclosure: The authors declared that this study received no financial support.

\section{References}

1. Fuller E, Welch JL, Backer JH, Rawl SM. Symptom experiences of chronically constipated women with pelvic floor disorders. Clin Nurse Spec 2005; 19:34-40; quiz 1-2.

2. Ross H. Constipation: cause and control in an acute hospital setting. Br J Nurs 1998; 7:907-913

3. Suominen M, Muurinen S, Routasalo P, Soini H, Suur-Uski I, Peiponen A, Finne-Soveri H, Pitkala KH. Malnutrition and associated factors among aged residents in all nursing homes in Helsinki. Eur J Clin Nutr 2005;59:578-583

4. Lämås K, Anudsson E, Stare AC, Jacobsson C. An interview study of the experience of middle-aged women living with constipation. Clin Nurs Stud 2015;3:1-7.

5. Mody R, Guerin A, Fok B, Lasch KL, Zhou Z, Wu EQ, Zhou W, Talley NJ. Prevalence and risk of developing comorbid conditions in patients with chronic constipation. Curr Med Res Opin 2014;30:2505-2513.

6. Guerin A, Mody R, Fok B, Lasch KL, Zhou Z, Wu EQ, Zhou W, Talley NJ. Risk of developing colorectal cancer and benign colorectal neoplasm in patients with chronic constipation. Aliment Pharmacol Ther 2014;40:83-92. 
7. Richmond JP, Wright ME. Review of the literature on constipation to enable development of a chronic constipation risk assessment scale. Clin Eff Nurs 2004;8:11-25.

8. Koloski NA, Jones M, Wai R, Gill RS, Byles J, Talley NJ. Impact of persistent constipation on health-related quality of life and mortality in older community-dwelling women. Am J Gastroenterol 2013;108:1152-1158.

9. Gage H, Goodman C, Davies SL, Norton C, Fader M, Wells M, Morris J, Williams P. Laxative use in care homes. J Adv Nurs 2010;66:1266-1272.

10. Petticrew M, Watt I, Sheldon T. Systematic review of the effectiveness of laxatives in the elderly. Health Technol Assess 1997;1:1-52.

11. Hosia-Randell H, Suominen M, Muurinen S, Pitkala KH. Use of laxatives among older nursing home residents in Helsinki Finland. Drugs Aging 2007;24:147-154

12. Bengi G, Yalçin M, Akpinar H. Kronik Konstipasyona Güncel Yaklaşım. Güncel Gastroenteroloji 2014;2:181-197.

13. Kaya N, Turan N. Konstipasyon Ciddiyet Ölçeğinin Güvenilirlik ve Geçerliliği. Türkiye Klinikleri, 2011;6:1491-1501.

14. Uysal N, Khorshid L, Eşer İ. The identification of constipation problem in healthy young individuals. TAF Prev Med Bull 2010;9:127-137.

15. Suares NC, Ford AC. Prevalence of, and risk factors for, chronic idiopathic constipation in the community: systematic review and metaanalysis. Am J Gastroenterol 2011;106:1582-1591.

16. Sendir M, Büyükyilmaz F, Asti T, Gürpinar S. Postoperative constipation risk assessment in Turkish orthopedic patients. Gastroenterol Nurs 2012;35:106-113.

17. Richmond JP, Wright ME. Development of a Constipation Risk Assessment Scale. Clin Eff Nurs 2005;9:37-48.

18. Kutlu AK, Yilmaz E, Çeçen D, Eser E. The reliability and validity of the Turkish version of the constipation risk assessment scale. Gastroenterol Nurs 2011;34:200-208.

19. Bub S, Brinckmann J, Cicconetti G, Valentine B. Efficacy of an herbal dietary supplement (Smooth Move) in the management of constipation in nursing home residents: a randomized, double-blind, placebo-controlled study. J Am Med Dir Assoc 2006;7:556-561.

20. Morad M, Nelson NP, Merrick J, Davidson PW, Carmeli E. Prevalence and risk factors of constipation in adults with intellectual disability in residential care centers in Israel. Res Dev Disabil 2007;28:580-586.
21. Pare P, Ferrazzi S, Thompson WG, et al. An epidemiological survey of constipation in canada: definitions, rates, demographics, and predictors of health care seeking. Am J Gastroenterol 2001;96:3130-3137.

22. Sandler RS, Jordan MC, Shelton BJ. Demographic and dietary determinants of constipation in the US population. Am J Public Health 1990;80:185189.

23. Bilgiç S, Dilek F, Arslan HS, Ünal A. Bir huzurevinde yaşayan yaşlıların konstipasyon durumları ve etkileyen faktörler. Int J Basic Clin Med 2016;4:9-16.

24. Mugie S, Benninga MA. Lorenzo CD. Epidemiology of constipation in children and adults: A systematic review. Best Pract Res Clin Gastroenterol 2011;25:3-18

25. Rasmussen LS, Pedersen PU. Constipation and defecation pattern the first 30 days after thoracic surgery. Scand J Caring Sci 2010;24:244-250.

26. Celik S, Atar NY, Ozturk N, Mendes G, Kuytak F, Bakar E, Dalgiran D, Ergin S. Constipation risk in patients undergoing abdominal surgery. Iran Red Crescent Med J 2015;17:23632.

27. Martin D. Physical activity benefits and risks on the gastrointestinal system. South Med J 2011;104:831-837.

28. Orhan C, Akbayrak T, Kaya S, Kav T, Kerem Güne M. Fiziksel aktivite seviyesi ile konstipasyon şiddeti arasındaki ilişkinin incelenmesi. Journal of Exercise Therapy and Rehabilitation 2015;2:66-73.

29. Uysal N, Khorshid L, Eşer İ. Sağlıklı genç bireylerde konstipasyon sorununun belirlenmesi. TAF Prev. Med Bull 2010;9:127-132.

30. Ucuzal M, Aldanmaz N. Genel cerrahi hastalarında ameliyat sonras konstipasyon riski. İnönü Üniversitesi Sağlik Bilimleri Dergisi 2015;4:1722.

31. Ayaz S, Hisar F. The efficacy of education programme for preventing constipation in women. Int J Nurs Pract 2014;20:275-282.

32. Gallagher PF, O'Mahony D, Quigley EM. Management of chronic constipation in the elderly. Drugs Aging 2008;25:807-821.

33. Robson KM, Kiely DK, Lembo T. Development of constipation in nursing home residents. Dis Colon Rectum 2000,43:940-943.

34. Howard LV, West D, Ossip-Klein DJ. Chronic constipation management for institutionalized older adults. Geriatr Nurs 2000;21:78-83.

35. Bailes BK, Reeve K. Constipation in older adults. Nurse Pract 2013;38:21 25. 